\title{
SECURITY INTERESTS IN MOTOR VEHICLES UNDER THE UCC: A NEW CHASSIS FOR CERTIFICATE OF TITLE LEGISLATION
}

Some states adopting the Uniform Commercial Code ${ }^{1}$ must integrate the Code's filing system for perfecting security interests in personalty with motor vehicle certificate of title acts currently in force. Adoption of the Code also raises problems pertaining to the recognition of security interests in motor vehicles by the courts of another state. The filing system embodied in Article Nine attempts to rationalize the interstate enforcement of security interests generally, but application of these provisions to motor vehicle security interests may prove particularly difficult because of the current diversity among state rules regarding the recognition of such interests. In addition to state rules, federal legislation also affects security interests in some motor vehicles, and this legislation too must be worked into the Code filing scheme. The importance of the motor vehicle as a form of chattel security 2 prompts an effort to explore some of the problems raised in this area by Article Nine of the Code.

Motor vehicle certificates of title were orginally developed to impede the sale of stolen motor vehicles. ${ }^{3}$ Certificate of title statutes usually provide for the issuance of certificates containing a detailed description of the vehicle and the identification of its owner, and further provide that title to a motor vehicle cannot validly be transferred unless the transfer is accompanied by assignment of the certificate. ${ }^{4}$ But certificate of title legislation also contains provisions relating to the creation of security interests in the vehicle. These provisions usually state that security interests in the vehicle can be perfected by notation on the certificate itself. 5 This recording system was created in

1. As of April 1, 1961, seven states had adopted the Uniform Commercial Code: Arkansas, Connecticut, Kentucky, Massachusetts, New Hampshire, Pennsylvania, and Rhode Island. See 1 \& 2 CCH Condit. SaIe-Chat. Mort. Rep. (1960). The state legislatures of a number of states were to consider adoption of the Code in their 1961 sessions. See Schnader, Report on the Statns of the Uniform Commercial Code, 78 BanKING L.J. 21 (1961).

2. See Kripke, The Modernization of Commercial Security Under the Uniform Commercial Code, 16 Law \& Contemp. Prob. 183, 187 (1951).

3. See, e.g., Mutual Fin. Co. v. Municipal Employees Union Local 1099, 110 Ohio Agp. 431, 439, 165 N.E.2d 435, 441 (1960) (dictum) ; Sims v. Sugg, 165 Kan. 489, 492, 196 P.2d 191, 194 (1948) (dictum) ; Taylor v. Burdick, 320 Mich. 25, 31, 30 N.W.2d 418, 421 (1948) (dictum).

4. See, e.g., VA. CoDE ANN. $\S \S 46.1-16,-80,-87$ (1958).

The contents of each certificate of title in use in 1958 is shown in picture form in Recording \& Statistrcal Corp., Automgobile Titrles and Transfers (1958).

5. See, e.g., OHro Rev. Code ANn. $\$ 4505.04$ (Page 1954); Iowa Code ANN. 321.45 (2) (Supp. 1960); IDAHo Code ANN. \$ 49-412 (1957). 
response to the inadequacy of ordinary chattel security recordation systems when applied to motor vehicle security interests. ${ }^{6}$ Under strict chattel mortgage or conditional sales laws, the sectred party is required to record his interest in the filing office of the city, township, or county in which the vehicle was located when the security interest attached, or in the local jurisdiction where the debtor then resided. ${ }^{7}$ In some states, a security interest filed in compliance with these requirements is valid against all subsequent purchasers anywhere within the state. ${ }^{8}$ Under these statutes, a purchaser is charged with the onerous duty of checking all possible places where a security interest in such a highly mobile chattel as a motor vehicle might have been recorded. Some states, on the other hand, give the purchaser partial protection by providing that a chattel security interest remains valid only for a limited time when the chattel is moved to another filing unit within the state. ${ }^{9}$ But these statutes only shift the burden to the secured party, who must follow the motor vehicle from county to county on pain of having his interest defeated by purchasers outside the county of original filing. The certificate of title notation system attempts to alleviate this problem, at least within the state, by creating a portable recording system which travels with the vehicle.

Forty jurisdictions have adopted certificate of title legislation. ${ }^{10}$ The remaining eleven states (nontitle act states) rely on filing systems set up under chattel mortgage acts, conditional sales acts, or the Uniform Commercial Code. ${ }^{11}$

Among the title act states, a majority have "complete" title acts. ${ }^{12}$ Most of these "complete" acts provide that perfection of security interests in a

6. See Leary, Horse and Buggy Lien Lave and Migratory Automobiles, 96 U. PA. L. Rev. 455 (1948).

7. See Goodrich, Conflict of Laws $\$ 157$ (conditional sales), $\$ 158$ (chattel mortgages) (3d ed. 1949) ; 2 BeALE, Conflict of LAws $\$ 272.2$ (conditional sales), $\$ 265.1$ (chattel mortgages) (1935) ; e.g., In re Stamford Auto Supply Co., 25 F. Supp. 530 (N.D. Tex. 1938) ; Beaver Creek Consol. Coal Co. v. Porter Mining Co., 60 F.2d 602 (E.D. Ky. 1929).

8. Ind. Ann. Stat. \$ 51-518 (1935) ; see Studebaker Bros. Co. v. Mau, 13 Wyo. 358, 80 Pac. 151, rehearing denied, 14 Wyo. 68, 82 Pac. 2 (1905).

9. See, e.g., Orda. Stat. Ann. tit. 46, § 58 (1954); Al.a. Code Ann. tit. 47, § 131 (1958).

10. Alaska, Arizona, Arkansas, California, Colorado, Delaware, District of Columbia, Florida, Hawaii, Idaho, Illinois, Indiana, Iowa, Kansas, Louisiana, Maryland, Michigan, Missouri, Montana, Nebraska, Nevada, North Carolina, North Dakota, New Jersey, New Mexico, Ohio, Oklahoma, Oregon, Pennsylvania, South Carolina, South Dakota, Tennessee, Texas, Utah, Virginia, Washington, West Virginia, Wisconsin, Wyoming. See Comment, 47 Calrf. L. Rev. 543, 576-86 Appendix (1959). Since the California Law Revicw completed its compilation, Connecticut has enacted a title act. Conn. GeN. Stat. ANn. \$\$14165-14-195 (1960).

11. Alabama, Georgia, Kentucky, Maine, Massachusetts, Minnesota, Mississippi, New Hampshire, New York, Rhode Island, Vermont. See Comment, supra note 10, at 574-75.

12. See Comment, supra note 10 , at 546 . 
motor vehicle can be achieved only by notation of the security interest on the certificate of title. Many exclude new car inventory, for which certificates are not usually granted until the vehicle is sold. ${ }^{13}$ Some, notably the Uniform Motor Vehicle Certificate of Title and Anti-Theft Act, ${ }^{14}$ exempt used car inventory as well. For those vehicles to which the "complete" title act does apply, local filing or recording statutes governing security interests in general personalty are inapplicable. ${ }^{15} \mathrm{~A}$ few complete title acts, however, contain no express provision making notation the exclusive method of recordation, and these might be construed to permit perfection of security interests in motor vehicles by other means. ${ }^{16}$ Under both kinds of "complete" title act, either the owner or the holder of the security interest ordinarily forwards the certificate covering the vehicle, together with an application stating the nature of the security interest being created, to a state noting agency which issues a new certificate revealing the security interest. ${ }^{17}$ If there is no certificate covering the vehicle, as in the case of new vehicles held for sale, a certificate showing the interest is issued when the chattel is sold. ${ }^{18}$ Depending upon the statute, the certificate may be delivered by the noting agency to the senior secured party, or to the party in possession of the vehicle. ${ }^{19}$

Under "incomplete" title acts, notation on the certificate of title is not required to perfect all security interests in a vehicle. These acts usually permit notation of security interests only when the vehicle is transferred. ${ }^{20}$ Unless there is a change in ownership when the interest is created, therefore, a party wishing to perfect his interest must rely on local recording statutes. ${ }^{21} \mathrm{~A}$ sub-

13. See, e.g., Fla. Stat. Ann. § 319.21 (1958) ; Pa. Stat. Ann. tit. 75, § 201(b) (1960); VA. CODE ANN. $\$ 46.1-117$ (1958).

14. Such statutes generally provide that no certificate of title need be obtained for a vehicle held by a dealer for sale. See ILr. ANN. Stat. tit. 95 I/2 § 3-102(2) (Smith Hurd 1958); Conn. Gen. Stat. Ann. \$ 14-166 (1960).

15. Alaska Comp. Laws Ann. $\$ 50-6-10(6)$ (Supp. 1958) ; Colo. Rev. Stat. Ann. \$ 13-6-19 (1954); IDAHo Code ANN. § 49-414 (1948). Such title acts usually supersede only the filing provisions of the earlier legislation. Provisions relating to the validity of the underlying security agreement generally remain applicable. Ibid. See 9B UNIFORAr LAwS ANN. $\$ 25$ \& Commissioners' Note. See, e.g., In re Ramsdell, Bkcy. No. 29448 (D. Conn. 1960); In re Reese, 33 Berks 93 (Pa. 1960).

16. E.g., Kansas, Oregon, and Washington. See Comment, supra note 10, at 578-86. Missouri and New Jersey require local filing as well as notation. Mo. Rev. Stat. Ann. \$ 443.480 (1952); N.J. STAT. ANn. § 39:10-11(c) (1961).

17. See, e.g., Colo. Rev. Stat. Ann. $\$ 13-6-22$ (1954); Conn. Gen. Stat. Ann. \$ 14-186 (1960); ArIz. Rev. Stat. Ann. $\$ 28-1310 B$ (1956).

18. New vehicle inventory is covered by manufacturer's or importer's certificates which must be transferred to the buyer on sale. This document is then forwarded with the application for a certificate of title. See, e.g., OHIo Rev. Code ANw. § 4505.05 (Page 1954); S.D. CoDE $\S 44.0202$ (Supp. 1952); IND. ANN. Stat. § 47-2503 (1952).

19. Compare Fla. Stat. ANn. $\$ 319.24$ (2) (Supp. 1960), with S.C. Code $\$ 46-139.47$, 139(22) (Supp. 1960).

20. See, e.g., W.VA. Code ANn. § 1721(122) (Supp. 1960); Ind. Ann. Stat. § 47-2501 (Supp. 1960) (No provision for noting subsequent liens except at transfer time).

21. See, Automobile Acceptance Corp. v. Universal C.I.T. Credit Corp., 216 Md. 344, 
sequent secured party, seeking to determine the existence of a prior encumbrance, is in no better position as to security interests acquired between transfers of ownership than he would be in a state with no certificate of title act at all. The "incomplete" title acts typically require the owner of a motor vehicle to make known all existing liens upon application for a new certificate, imposing criminal penalties for failure to comply. ${ }^{22}$ It has been held, however, that the secured party who records his interest in another manner remains protected whether or not the owner of the vehicle complies with this duty. ${ }^{23}$

In states without certificate of title legislation, annual registration protects against theft and provides a convenient means for levying taxes on motor vehicles. ${ }^{24}$ Owners of motor vehicles must usually notify a central department of any transfer and must also assign the certificate of registration to the transferee. ${ }^{25}$ But holders of security interests in motor vehicles must seek protection under a local recording system. ${ }^{26}$

The problem of where to record a security interest in a motor vehicle is dramatized once the chattel is driven to another jurisdiction and sold. While the hornbook rule is that the validity of a security interest in a chattel is governed by the law of the situs of the chattel when the interest is created, ${ }^{27}$ subsequent purchasers or lien creditors often prevail over security interests perfected "out-of-state."28 Courts of the second state often reach this result by holding that the secured party has committed some form of negligence, such as lack of diligence in pursuing the vehicle, clothing the debtor with indicia of title, or negligence in extending credit to the defrauding debtor. ${ }^{29}$ A few states have provided a grace period during which a security interest in an incoming vehicle remains perfected; in these states the secured party is thereby afforded an opportunity to overtake the vehicle and re-perfect his interest. ${ }^{30}$

352,139 A.2d 683, 687 (1957) (application of recording statute to motor vehicle encumbrances assumed without discussion).

22. E.g. Inp. Ann. Stat. § 47-2501, -2506 (1952) ; Mp. Ann. Code art. $66 \mathrm{I} / 2, \S \S 24$ (a) (3), 46 (1957) ; N.D. REv. Code $\$ \$ 39-05-05(3), 39-05-33$ (1960).

23. Commercial Credit Corp. v. Schneider, 265 Wis. 264, 61 N.W.2d 499 (1953).

24. See Townsend, The Case of the Mysterious Accessory, 16 Law \& Contemp. Prob. 197, 199 (1951).

25. See, e.g., Ala. Code tit. 51 § 706 (1940) ; N.H. Rev. Stat. Ann. § 260:19 (1955).

26. But cf. GA. CODE ANN. $\$ 68-207$ (1933) (note liens on application for registration certificate.)

27. Goodrich, Conflict of Laws $\$$ 157-58 (3d ed. 1949); 2 Beale, Conflict of LAWs $\S \S 265.1,272.2$ (1935).

28. Four cases, decided in 1947, protected local parties against out-of-state security interests. Leary, Horse and Buggy Lien Law and Migratory Automobiles, 96 U. PA. L. Rev. 455, 461-68 (1948) (analyzing cases).

29. See Comment, 47 Calif. L. Rev. 543, 556-68 (1959).

30. E.g., Conn. Gen. Stat. Ann. \$ 14-185 (1960); Ill. Ann. Srat. ch. 951/2, § 3-202 (Smith-Hurd 1958) ; Ark. Stat. AnN. $§ 75-160$ (c) (Supp. 1959). All of these sections were borrowed from the Uniform Motor Vehicle Certificate of Title and Anti-Theft Act, 9B UNIFORM LAwS ANN. \$ 20 (1955). 
But the position of a secured party who has not perfected his interest in the new jurisdiction remains precarious.

\section{Problems under the Uniform Comarercial Code}

In jurisdictions which adopt the Uniform Commercial Code, the Secured Transactions Article must be reconciled with the pre-existing law governing security interests in motor vehicles. When the Code is passed by nontitle act states this adjustment is simple: the Code's filing system is used to perfect security interests in all chattels, including motor vehicles. In so far as title act jurisdictions are concerned, the Code's drafters foresaw the apparent inconsistency between Article Nine's filing system for all forms of personalty and the certificate of title method of perfecting security interests through notation. ${ }^{31}$ Section 9-302(3) (b) of the Code offers two different methods for incorporating title acts into Article Nine. Under Alternative $A$, title acts remain the exclusive means of perfecting interests in motor vehicles even after adoption of the Code. This provision should be chosen only in states with "complete" title acts which provide that notation is the exclusive method of perfecting security interests. ${ }^{32}$ Alternative $B$, on the other hand, is available for a title act state in which notation is simply a permissible method of perfecting security interests. Alternative $B$ applies if "notation of . . . a security interest can be indicated. . . on a certificate."33 Section 9-302(4), however, deftly converts any title act which merely permits notation into a mandatory-notation title act:

A security interest in property covered by a statute described in subsection (3) can be perfected only by .... indication of the security interest on a certificate of title or a duplicate thereof by a public official. . $^{34}$

In those states where a security interest cannot be perfected by notation unless the ownership of the vehicle is transferred, ${ }^{35}$ any interest which attaches between transfers of the vehicle would not seem to be an interest which "can be indicated" on the certificate of title within the meaning of Alternative $B$. If this interpretation is correct, such an interest can be perfected only through Article Nine filing. Presumably an interest created between tranfers of ownership would be noted on the certificate of title issued when the vehicle is next transferred. On the other hand, "can be indicated" might be interpreted to mean "can ever be indicated." Under this interpretation of

31. The May 1949 Draft of the Uniform Commercial Code contained a complete title act incorporated into the Code. UNIForM CoMMmerctal CoDE $\$ 7-801$ (May 1949 Draft).

32. Apparently, if the Code was enacted in Missouri which requires both notation and filing to perfect a security interest in a motor vehicle, the filing requirement would no longer apply. Local filing systems would be displaced by the Article Nine filing system. See note 16 supra.

33. UCC § 9-302(3) (b) alt. B. (Emphasis added.)

34. Emphasis added.

35. See notes 20-22 supra and accompanying text. 
Alternative $B$, the adoption of Alternative $B$ would have the effect of making Article Nine filing provisions inapplicable to security interests created $b e-$ tween transfers of ownership, since such interests can be perfected by notation whenever the vehicle is transferred. In that case, security interests created between transfers would be governed by the existing title act. But this reading of Alternative $B$ creates problems. The incomplete title acts make no provisions for notation before such time as title to the vehicle is transferred. ${ }^{36}$ Section 9-302(4), on the other hand, provides that notation on the certificate becomes the exclusive method of perfecting those security interests which are exempted from Article Nine filing by Alternative $B$. Thus, joining "incomplete" title acts with section 9-302(4) leads to an anomalous result; the secured party has no way to perfect his interest until title to the vehicle is transferred. The only way to avoid this problem would be to construe section 9-302(4) as authorizing the state notation agency to make notations on the certificate at any time. It is doubtful, however, that a general statement of law can by itself constitute a directive to administrative officers, governed by a specific statute, to expand their functions by taking on these additional duties.

\section{Inventory Vehicles}

Although Alternative $B$, as modified by section $9-302(4)$, is to a significant degree identical with Alternative $A$, there may be a critical difference between the two alternatives in the particular case of used vehicles held for sale by a dealer. While certificates of title are not usually issued for new inventory vehicles, used vehicles are covered by such certificates, assigned to the dealer by former owners. ${ }^{37}$ In some states, security interests in used vehicle inventory are governed by the title act and must be recorded on the certificates. ${ }^{38}$ If Alternative $A$ is adopted in such states, the title act will continue to apply to security interests in such vehicles..$^{30}$ The differently worded provisions of Alternative $B$, on the other hand,

\section{Ibid.}

37. See, e.g., Iowa Code Ann. \$321.45(2) (Supp. 1960) ; Mont. Rev. Codes § 53-109 (c) (1954); Tex. PEN. CODE art. 1436-1, § 33 (1953).

38. In the absence of a specific exclusion for inventory vehicles, the inclusion of such interests arises from the general provisions requiring certificates of titles for all vehicles. For cases requiring notation on the certificate of security interests in inventory vehicles see Metropolitan Fin. Corp. v. Morf, 42 Cal. App. 2d 756, 109 P.2d 969 (Dist. Ct. App. 1941); Buss v. McKee, 115 Colo. 159, 170 P.2d 268 (1946) ; Sorenson v. Pagenkopf, 151 Kan. 913, 101 P.2d 928 (1940); Rasmussen v. O. E. Lee \& Co., 104 Mont. 278, 66 P.2d 119 (1937). See generally Townsend, supra note 24 , at 224-7.

39. Alternative $A$ exempts from Article 9 filing all security interests for which a state statute "requires" notation on the certificate of title. It makes no distinction between inventory and noninventory vehicles. Where security interests in used vehicles are covered by certificates of title, and must be noted, therefore, they would remain included within the title act. 
suggest that Article Nine's filing system becomes the sole means of perfecting security interests in all inventory vehicles, new or used. ${ }^{40}$ Thus the applicable law governing security interests in used inventory vehicles will differ depending upon whether Alternative $A$ or $B$ is enacted.

This difference may give rise to two different sets of relationships between parties holding security interests in the dealer's inventory and subsequent buyers of the used vehicles. Under the Code, a buyer in the ordinary course of business takes "free of a security interest created by his seller even though it is perfected and even though the buyer knows of its existence." 41 Section 1-201(9) defines "a buyer in ordinary course of business" as one who takes from a person in the business of selling goods of that kind "without knowledge that the sale to him is in violation of the ownership rights or security interest of a third party in the goods ...." The Code defines "knowledge" as actual knowledge," so that the buyer would appear to "know" the sale

40. $\operatorname{LCC} \$ 9-302(3)$ (b) alt. B :

(3) The filing provisions of this Article do not apply to a security interest in ...

Alternative B

(b) ... a motor vehicle which is not inventory held for sale for which a certificate of title is required under the statutes of this state....

It is possible to read this section as excluding from Article Nine filing only security interests in "a motor vehicle which is not [inventory held for sale for which a certificate of title is required] ...." The bracketed phrase refers only to used vehicle inventory, and so interpreted would mean that only used vehicle inventory would be exempt from Article Nine filing. Such a reading would remove all non-inventory vehicles from the coverage of the title act and make Article Nine filing the sole method of perfecting security interests in those vehicles. This is an undesirable result. UCC 9-302 Comment 8 . The better reading would exclude from Article Nine filing only security interests in "a motor vehicle [,] which is not inventory held for sale [,] for which a certificate of title is required under the statutes of this state."

Alternative $B$ would thus appear to alter the pre-Code law of some title act states with regard to purchases of used vehicles from inventory. These provisions of the Code do not specifically state that they amend existing title acts. As a result, one might invoke the rule that general statutes (i.c. the Code) should not be construed as an implied repeal of prior statutes covering particular phases of the same subject. See 1 SutererLand, Statutory Construction \$2021 (3d ed. 1943) [hereinafter cited as Sutherland]. But alternative construction of Alternative $B$ to conform with prior law seems impossible. Moreover, the next subsection, § 9-302(4), demonstrates another specific conflict with permissive "complete" title acts, a clear implied amendment of prior law. The general rule of construction in cases of conflict between existing statutes is that "the prior law yields to the extent of the conflict." 1 SutherLand \$ 2012; cf. Weisel v. McBride, 191 Pa. Super. 411,156 A.2d 613 (1959) (court interpreting Code refused to subordinate a buyer in the ordinary course of business to security interest noted on a certificate of title after buyer had paid purchase price).

41. UCC $\$ 9-307(1)$. The phrase "created by his seller" indicates that the buyer in the ordinary course of business may not take free of an interest created by someone other than "his seller." Thus, when $A$ borrows from $B$ on the security of $A$ 's car, $A$ later selling the vehicle to a dealer, $B$ 's properly perfected interest may prevail over a buyer in the ordinary course of business from the dealer.

42. UCC § 1-201(25). 
violates rights of a third party only if he knows that there is a security agreement, and that the agreement prohibits sale by the dealer. Even then, if the buyer knows that the secured party has entrusted the goods to a dealer, it might not be unreasonable for the buyer to assume that the secured party has waived any prohibition on sale. Support for such a view might be found by analogy to Article Two, which expressly provides that "any entrusting of possession of goods to a [dealer] gives him power to transfer all rights of the entruster to a buyer in ordinary course of business." 43 The Code's position has been followed in a number of nontitle act jurisdictions and jurisdictions in which notation is not the exclusive method of perfection. Buyers in the ordinary course of business have been allowed to prevail over security interests perfected through chattel mortgage or conditional sales filing systems. If it is not expressly permitted by statute, ${ }^{44}$ this result is reached on the theory that a mortgagee who permits a dealer to display a mortgaged vehicle for sale impliedly consents to the sale free of the encumbrance. ${ }^{45}$ Even in mandatory notation states, a number of title acts expressly protect buyers in the ordinary course of business. ${ }^{46}$

When, however, the statute provides that notation will give notice to "purchasers" and this is coupled with a requirement that a certificate be transferred to prevent the sale from being void, 47 the problem of protecting buyers in the ordinary course of business becomes more difficult for courts. Such buyers have often prevailed when they have been deceived by a fraudulently obtained "clean" certificate. ${ }^{48}$ The Virginia court has gone further, allowing a buyer in the ordinary course of business to prevail over a secured party whose interest was properly noted and who was in possession of the certificate. $^{49}$ This decision seems to have been reached on the theory that the secured party had waived the express provisions of the statute relating to "notice to purchasers" by permitting the vehicle to be offered by a dealer for sale. ${ }^{50}$ Despite examples of bending title acts in this fashion, it seems reasonable to conclude that express statutory provisions charging buyers with constructive notice will impede recognition of the traditional policy of protecting buyers in the ordinary course of business. Sound commercial

43. UCC \& 2-403(2).

44. For an explicit statutory provision, see, e.g., N.Y. LIEN LAw § 230-c(6) (McKinney, Supp. 1960).

45. See Fogle v. General Credit Inc., 122 F.2d 45 (D.C. Cir. 1941) ; cf. Buss v. McKee, -115 Colo. 159, 170 P.2d 268 (1946).

‥ 46. E.g., Ill. Ann. StAT. tit. 95 1/2, § 3-201(c) (Smith-Hurd 1958); Conn. Gen. Stat. ANn. \$ 14-6 (1960).

47. E.g., Ohio Rev. Code AnN. $\S 4505.04,4505.13$ (Page 1954); Utar Code Ann. \$ 41-1-72 (1960) ; Mont. Rev. Code \$ 53-109(d) (1954).

48. See, c.g., Sorenson v. Pagenkopf, 151 Kan. 913, 101 P.2d 928 (1940); Rasmussen v. O. E. Lee \& Co., 104 Mont. 278, 66 P.2d 119 (1937).

49. General Credit Inc. v. Winchester, Inc., 196 Va. 711, 85 S.E.2d 201 (1955).

50. Ibid.; see Note, 45 VA. L. REv. 754, 761 (1959). 
policy dictates that Alternative $B$ be enacted by all Code states whose title acts govern used car inventory and do not specifically protect buyers in the ordinary course of business..$^{51}$ Buyers who know that they will be subordinated to noted security interests may be discouraged from purchasing used motor vehicles. And it is to the advantage of both the dealer and his financing agency to stimulate consumer purchases of inventory; the proceeds received upon disposition of a vehicle are the major concern of the dealer and also the source of repayment to the financer. ${ }^{52}$

\section{Unperfected Security Interests}

Another conflict between the Code and certificate of title legislation concerns the consequences of a failure to perfect a security interest. In some title act jurisdictions any interest that is not recorded on the certificate will not be recognized. The putative secured party is treated as a general unsecured creditor, with "no right, title, claim, or interest in the vehicle." 53 On the other hand, the Code provides that where its filing system is the means of perfecting security interests in any chattel, failure to perfect does not result in the loss of all rights in that chattel. ${ }^{54}$ Rather, the unperfected interest is simply subordinated under section 9-301 to properly perfected interests to certain lien creditors, and to insolvency representatives. This difference in the status of the unperfected security interest may have many consequences. Under the title act rule, for example, a secured party who attempts to realize the value of the vehicle by taking possession or by disposing of it can be restrained by general creditors upon the theory that he has no "right, title, claim or interest" in the vehicle. ${ }^{56}$ Under the Code, an unperfected secured party's rights in the vehicle extend to possession and disposition upon the debtor's default. ${ }^{67}$ State title acts containing the strict

51. Of the seven states which have enacted the Code, only Pennsylvania, Connecticut, and Arkansas have title acts. Pennsylvania originally chose Alternative $A$. PA. STAT. ANN. tit. 12A, $\S 9-302$ (2) (b) (1954). In 1959, Pennsylvania replaced Alternative $A$ with Alternative B. PA. Stat. AnN. tit. 12A, \$9-302(3) (b) (1960). Connecticut enacted Alternative A. Conn. Gen. Stat. AnN. \$ 42a-9-302 (1960). Arkansas enacted Alternative $A$. Acts 1961, No. 1S5, $\$ 902(3)$ (b). Although Kentucky requires notation of security interests on the registration certificate covering the vehicle, KY. REv. STAT. ANN. $\$ 186.195$, (Supp. 1951), security interests in motor vehicles are subject to Article Nine filing, Ky. Rev. Stat. Ann. $\$ 382.740$.

52. On the problems of used vehicle inventory financing, see Skilton, Cars For Sale: Some Comments on the Wholesale Financing of Automobiles, 1957 Wrs. L. REv. 352, 390-408.

53. See e.g., Ohio Rev. Code AnN. § 4505.04 (Page 1954); Iowa Code Ann. § 321.45(2) (Supp. 1960); IDAHo CoDE ANN. § 49-404 (1957).

54. E.g., UCC $\$ 9-503$ (right to possession after default); UCC § 9-504 (right to dispose of collateral after default).

56. See Ohio Rev. Code Ann. $\$ 4505.04$ (Page 1954).

57. See note 54 supra. 
provision should be amended to conform to the general policy of the Code toward unperfected security interests.

The Code provisions governing the effect of delayed perfection of a security interest may conflict with what appears to be the rule under a few title acts. The Code provides that, between an unperfected interest and a general creditor without knowledge of the interest, the first to perfect or to obtain a judicial lien will prevail. 58 The requirement that the lien creditor be "without knowledge" means that a prior judicial lien will not prevail over an unperfected interest if the lienor had actual knowledge of the unperfected interest at the time he secured the lien. Here, the Code's position conflicts with a body of chattel mortgage and conditional sales law that has grown up around the New York rule announced in Karst v. Gane. ${ }^{59}$ In at least seven states ${ }^{60}$ the chattel mortgage laws provide that a mortgage not filed immediately upon execution of the security agreement, or within a reasonable time thereafter, can be avoided by any general creditor who had extended credit prior to the filing of the mortgage, or, in some states, in the gap between creation and perfection of the interest. Prior general creditors will prevail even if they obtain judicial liens after the security interest has been perfected. This rule seems to have been incorporated explicitly in at least one certificate of title act, ${ }^{61}$ and may be engrafted by courts on to others. ${ }^{62}$ While the rule itself might not operate harshly as a penalty for late filing of the security interest, it has a particularly disastrous effect in bankruptcy. Under the rule of Moore $v . B a y, 63$ the existence of one prior creditor will enable the trustee to defeat the security interest entirely. The Code position seems to have been taken to defeat this possibility, reasoning that creditors

58. UCC $\S 9-301(1)(b)$.

59. 136 N.Y. 316,32 N.E. 1073 (1893).

60. Cases interpreting statutes in this manner include: Ruggles v. Cannedy, $127 \mathrm{Cal}$. 290, 53 Pac. 911 (1899); Production Credit Ass'n v. Kent, 143 Me. 145, 56 A.2d 631 (1948) ; Thomas Roberts \& Co. v. Robinson, 141 Md. 37, 118 At1. 198 (1922) ; see Friedman v. Sterling Refrigerator Co., 104 F.2d 837, 841 (4th Cir. 1939) ; Ransom \& Randolph Co. v. Moore, 272 Mich. 31, 261 N.W. 128 (1935) ; Pearson v. Lafferty, 197 Mo. App. 123, 193 S.W. 40 (1917); Union Nat'l Bank v. Oium, 3 N.D. 193, 200-01, 54 N.W. 1034, 1036 (1892) ; Hollenbeck v. Louden, 35 S.D. 320, 152 N.W. 116 (1915); Brockhurst v. Cox, 71 N.J. Eq. 703, 64 Atl. 182 (Ch. 1906), aff'd, 72 N.J. Eq. 950, 73 Atl. 1117 (Ct. Err. \& App. 1907).

61. The New Jersey act specifies that application for notation must be made within five days after the execution of the security interest or there shall be the same result of failure to record as exists under the chattel mortgage statute. N.J. STAT. ANN. $\$ 39$ : 10-11 (1961). Failure to record a chattel mortgage within five days makes the security interest "absolutely void as against the creditors of the mortgagor," Id. $\S 46: 28-5$. See Brockhurst v. Cox, supra note 60 . (delayed recordation invalid against existing creditors, valid as to subsequent creditors).

62. The California statute's provision that 30 days constitutes a "reasonable time" for application for notation of a chattel mortgage covering a motor vehicle, while it seems to attempt to relax the rule, might nevertheless be construed to incorporate it by the reference to "reasonable time." CaI. Ver. Code $\$ 6300$ (b).

63. 284 U.S. 4 (1931); see 4 CollIER, BANKRUPTCY \ 70.95 (14th ed. 1959). 
who have relied upon the general credit of the debtor instead of taking security are in no position to complain when either perfected or unperfected interests prevail over them. Although the Code does not purport to amend certificate of title acts in this respect, adoption of the Code will have the effect of repealing the Karst v. Gane rule in title acts wherever its application there is based on specific or implied reference to codification of the rule in the state's chattel mortgage act; the Code explicitly repeals the underlying chattel mortgage acts. ${ }^{b 4}$ To the extent that the Karst rule currently survives as a common law rule, it would nevertheless seen preferable to treat the Code's policy as governing.

\section{The Date of Perfection}

The Code's lien creditor test requires that the lien be obtained prior to the perfection of a competing security interest. ${ }^{65}$ A divergency exists between title acts in their determination of when a security interest in a motor vehicle is perfected. Some acts date perfection from the time the application for notation is filed with the noting agency. ${ }^{66}$ Others state that constructive notice of a security interest dates from the time it is noted on the certificate. ${ }^{67}$ The Code displays a similar ambivalence. For most security interests perfection dates from the receipt of an application for perfection by the filing officer. ${ }^{88}$ When an existing title act is made applicable to motor vehicles, on the other hand, section 9-302(4) declares that perfection can only be achieved "by indication on the certificate of title." While this distinction in the Code might, on its face, seem inconsistent, it may be explained by the nature of the perfection systems governing motor vehicles and those controlling more common chattels. The certificate of title system is based on actual notification to subsequent secured parties through the certificate itself. On the other hand, the Code fling system is founded on constructive notice given through recordation.

The difference between these rules has practical significance only when some mistake is made by the filing or noting officer. Modification of all title acts to date perfection from the time applications for notation were received might avoid the possibility that the second of two applications received might be the first noted. However, it would not solve the problem raised when an interest is not noted at all. ${ }^{69}$ In that case, a subsequent secured party

64. UCC § 10-102.

65. UCC \$ 9-301(1) (b) \& comment 2.

66. E.g., D.C. CODE ANN. \& 40-703(d) (1951); Nev. Rev. STAT. $\$ 482.440$ (1960); N.M. Stat. ANN. $\S 64-5-1$ (d) (1953). Relation back provisions in some statutes date perfection as of the time the security agreement was executed if it was filed or noted within a specified period. See, e.g., S.C. Code ANN. § 46-139.84 (Supp. 1960).

67. See, e.g., Fra. Stat. Ann. $\$ 319.27(2)$ (1958); Mo. Rev. Stat. Ann. $\$ 443.480$ (1949) ; Neb. Rev. Stat. AnN. \$60-110 (1952).

6S. UCC \$ 9-403(1) \& comment 1 .

69. Cf. Securities Credit Corp. v. Pindell, 153 Neb. 298, 44 N.W.2d 501 (1950) (failure of clerk to note lien on certificate.) 
might take a vehicle covered by a "clean" certificate only to discover that constructive notice of a prior unnoted interest dated from the time the application for notation was received.

In one Code jurisdiction amendments have been proposed to section 9-302 (4) and to the title act, providing that notation shall be dated from the time the certificate is delivered to the commissioner of motor vehicles. ${ }^{70}$ This proposal conforms perfection under the title act to the rest of the Code. One difficulty which seems to inhere in this approach is the apparent necessity of providing for time-stamping and filing of applications at the office of the notation agency, a practice which may not be customary in those states which date perfection from the time of notation on the certificate.

\section{Proceeds from the Sale of the Vehicle}

Under the Code, a properly perfected security interest is protected against sale of the vehicle in several ways. Section 9-306(2), which will govern motor vehicle interests in nontitle act states, ${ }^{71}$ provides that a security interest "continues in any identifiable proceeds including collections received by the debtor." Proceeds is defined broadly enough to include either cash or a vehicle received in trade- "whatever is received when collateral or proceeds is sold, exchanged, collected or otherwise disposed of."72 The secured party's interest in proceeds is considered perfected "if the interest in the original collateral was perfected."73 However, perfection ceases ten days after receipt of the proceeds by the debtor unless the financing statement filed by the secured party covered proceeds as well as the original collateral, or unless the debtor perfects an interest in the proceeds by filing an appropriate financing statement within the ten day period. ${ }^{74}$ In insolvency proceedings, a financing statement that covers proceeds would also perfect the holder's interest "in all cash and bank accounts of the debtor" even if the cash proceeds were commingled or deposited in a bank account. ${ }^{75}$

70. Copy of proposed amendments on file in Yale Law Library. If the application is filed within ten days of execution, the date of perfection relates back to the day of creation.

71. Article Nine's general filing provisions apply to motor vehicles in nontitle act states. UCC $\$ 9-302(3)(\mathrm{b})$.

72. UCC \& 9-306(1).

73. UCC $\$ 9-306(3)$.

74. UCC $\S \S 9-306(3)(a),-(b)$.

75. UCC $\$ 9-306$ (4) (d). This interest in unidentifiable proceeds is "limited to an amount not greater than the amount of any cash proceeds received by the debtor within ten days before the institution of the insolvency proceedings." UCC $\$ 9-306$ (4) (d) (ii).

The validity of the proceeds sections of the Code in a federal bankruptcy proceeding will turn on whether or not the "continuously perfected" security interest in the unidentifiable proceeds is construed to be a lien or a state-created priority. See 52 Stat. 874 (1938), as zmended, 11 U.S.C. $\$ 104$ (1958); 4 CollIER $\$ 70.58,3$ Collier $\$$ 64.02. Compare In re Harreth MLotors, Inc., 135 F. Supp. 863 (M.D. Tenn. 1955) (construing $\$ 9-306$ 's prede-

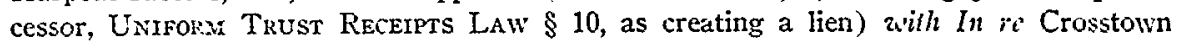
Motors, 272 F.2d 224 (7th Cir. 1959), cert. denied, 363 U.S. 811 (1960) (construing the 
In the event of an unauthorized sale of an encumbered vehicle, the secured party need not rely on the availability of proceeds for the sole protection of his security interest. Under section 9-306(2) the interest in the vehicle continues, even after it has been sold or otherwise transferred, unless the sale "was authorized by the secured party in the security agreement or otherwise ...."70 The sale of vehicles which are inventory held for sale is almost always authorized.77 As to noninventory vehicles, the Code's drafters note that "a claim to proceeds in a filed financing statement might be considered as impliedly authorizing sale or other disposition of the collateral, depending upon the circumstances of the parties, the nature of the collateral, the course of dealing of the parties, and the usage of the trade."78 Such an implied authorization might arise, for example, in the case of an automobile rental agency which replaces its fleet at the end of the model year. Such sales would seem to be in accord with the usage of the trade. The opposite inference might be raised if an income producing truck were sold for cash, since the security interest might not be adequately recompensed from the proceeds of a sale. Close cases involving implied authorization to sell might be resolved by amending section 9-402(3) of the Code to provide that the secured party must note on the financing statement whether or not he agrees to a sale; failure to make an explicit statement, in conjunction with a demand for proceeds, could be considered an implied authorization to sell.

Title act states enacting Alternative $B$ of section 9-302(3) face other problems. Under Alternative $B$ security interests in motor vehicles which are not "inventory held for sale" are exempted from Code filing and can be perfected only by notation on a certificate of title. ${ }^{79}$ Conceivably, section 9-302(3) might be construed to make the Code's filing system inapplicable only to the security interest in the vehicle itself, so that enactment of Alternative $B$ would not preclude use of Code filing to pre-perfect an interest in proceeds at the same time that the security interest in the vehicle is perfected by notation. On the other hand, subsection (3) might be construed more broadly, to make Code filing inapplicable to the entire transaction. In this case, no financing statement is available to "pre-perfect" an interest in proceeds. The secured party's interest in proceeds would then have to be perfected "before the expiration of the ten day period" following the debtor's receipt of these proceeds. ${ }^{80}$ If the proceeds are cash, the secured party must seize the funds within ten days or lose his perfected status; under the Code possession is the only

$\$ 10$ interest as a priority). See also 2 B.C. IND. \& CoMrar. L. REv. 73, 83-84 (1960) ; Kennedy, The Trustee in Bankruptcy Under the Uniform. Coinmercial-Code: Some Problens Suggested by Articles 2 and 9, 14 RUTGers L. Rev. 518; 531-34 (1960).

76. UCC $\$ 9-306(2)$. Of course, the secured party may have but one satisfaction. Id. at comment 3.

77. See Skilton, supra note 52, at 354. See text at note 43 supra.

78. UCC § 9-306 comment 3 .

79. See $\$ 9-302(4)$.

80. UCC \& 9-306(3) (b). 
method of perfecting an interest in cash. ${ }^{81}$ For most noncash proceeds, the secured party can perfect his interest by filing a financing statement covering them within ten days. ${ }^{82}$

Under either the broad or the narrow construction of 9-302(3), perfection of an interest in proceeds will be difficult in cases where the debtor receives a vehicle as proceeds. The secured party would have to obtain the title certificate of the "proceeds" vehicle and present it to the noting agency with the security agreement containing the claim to proceeds. State title acts generally speak in terms of presenting a "chattel mortgage" to the noting agency, ${ }^{33}$ and since the permissible scope of such security agreements is defined by the Code where enacted, ${ }^{84}$ a security agreement covering proceeds would presumably be cognizable by the noting agency. In addition, if the sale is made to buyers not in the ordinary course of business the security interest will remain perfected in the original vehicle by virtue of the title act provisions governing subsequent purchasers. ${ }^{85}$

The same consequences may ensue in title act states enacting Alternative $A$, but the difficulty in perfecting an interest in proceeds may also extend to proceeds from the sale of inventory vehicles. If the title act requires that security interests in used vehicle inventory be recorded by notation on the certificate $^{86}$ that notation procedure continues in force under Alternative $A .{ }^{87}$ In other words, the Code filing system will not be available for security interests in used vehicle inventory. As in the case of noninventory vehicles under Alternative $B$, the secured party may not be able to pre-perfect his interest in non-vehicle proceeds, and will be required to obtain the certificate and apply for a notation in order to perfect an interest in trade-in vehicles. States whose title acts apply to used vehicle inventory could avoid these difficulties in the field of inventory financing by enacting Alternative $B$.

\section{After-Acquired Property}

The security agreement between the debtor and the holder of the security interest may provide for the attachment of that interest to subsequently acquired property. ${ }^{88}$ Arrangements of this kind might arise in the context of long term financings covering a large number of vehicles owned by a single debtor.

81. See UCC $\$ 9-306$ comment 2 (c), which states that those who receive funds paid out from a comingled account in the operation of the debtor's business take free of security interests.

82. UCC $\$ 9-306(3)(\mathrm{b})$.

83. See, e.g., Mont. Rev. Codes Ann. \$ 53-110(a) (1954); N.M. Stat. Ann. 64-51(b) (1960) ; Onio Rev. Code AnN. 4505.13 (Page 1954).

84. The Code is substituted for chattel mortgage acts and similar statutes, which are explicitly repealed. UCC \$ 10-102.

85. See note 8 supra and accompanying text.

86. See note 38 supra and accompanying text.

87. See note 39 sipra.

88. UCC $\$ \$ 9-204(1),-(3)$. 
Perfection of an interest in the after-acquired motor vehicles of a debtor is relatively simple whenever, as in nontitle act states, the Code filing system applies to motor vehicles. Under the Code, the secured party is simply required to claim after-acquired property in the security agreement and to describe the types of collateral secured in the financing statement. ${ }^{89}$

Since financing statements are not available to perfect security interests in after-acquired noninventory vehicles in title act states, a secured party in those states must police the acquisitions of his debtor and be certain that he notes his interest on every certificate of title. This obligation may be particularly onerous when the security interest covers a large number of vehicles. The simplicity of the Code's single financing statement might be achieved, however, if title acts were amended to authorize a special type of title certificate which could cover a number of vehicles owned by one debtor..$^{90}$ For purposes of perfecting interests in after-acquired property, the application for a fleet certificate could be designated by the parties as a continuing authorization to the noting agency to note the secured party's interest in each vehicle acquired by the debtor subsequent to the execution of the security agreement. The use of fleet certificates to cover after-acquired vehicles would require several innovations. First, the system would operate best if there were a single statewide noting agency. Second, the following procedure would be required to make sure that new vehicles purchased by the debtor are noted on his fleet certificate: The noting agency must keep a file containing copies of all such fleet certificates. All applications for a certificate would have to be checked against the file to determine whether the transferee is subject to an outstanding fleet certificate which contains an after-acquired property clause. This procedure would be a relatively simple task in each case, since there probably will be few fleet certificates in the file of any one state. If the transferee is subject to such a fleet certificate, the noting agency would then cancel the certificate of title currently covering the purchased vehicle, and would record a description of that vehicle on the debtor's existing fleet certificate. Conversely, when a fleet vehicle is sold, the debtor-transferor would have to present the fleet certificate to the noting agency. The title act might provide an added check against unauthorized sale of fleet vehicles by granting possession of the certificate to the

89. UCC $\$ \$ 9-204(3),-402(1)$. Section 9-108 of the Code attempts to protect afteracquired property agreements from a bankruptcy trustee's challenge that they are voidable preferences. In amplification of that provision the comment to it asserts that "interests in after-acquired property have never been considered as involving transfers of property for antecedent debt merely because of the after-acquired feature ...." UCC $\$$ 9-108 comment 1. On the other hand, critics of this position assert that security interests in after-acquired property are "really" given for an antecedent debt. Kennedy, supra note 75, at 546-49. See generally Friedman, The Bankruptcy Preference Challenge to After-Acquired Property Clauses under the Code, 108 U. PA. L. Rev. 194 (1959).

90. The suggestion of a fleet certificate was made in the May 1949 Draft of the Uniform Commercial Code, $\$ 7-\$ 13$. The following description, however, differs materially from the sketchy Code proposal, which seemed to contemplate certificates covering identical vehicles which would not be described separately on the document. 
obligation gives value to enable the debtor to acquire rights in or the use of The agency would strike the description of the vehicle sold from the fleet certificate and issue an ordinary single vehicle certificate to the transferee. Under the usual practice of title act notation, the secured party's interest would usually be noted on the new certificate issued to the transferee. This practice could create problems for the fleet owner who makes periodic replacements of his fleet by trading-in the old vehicles, since the trade-in value of old vehicles would be reduced if they were traded subject to the secured party's interest. This problem could be avoided, however, by resort to the existing practice of allowing a secured party to release his interest in a vehicle. In the case of fleet certificates, the debtor might be required to obtain specific releases for each vehicle sold; alternatively, a security agreement noted on the fleet certificate might provide for an automatic release whenever a replacement of vehicles is effected.

Both the fleet certificate and the Code's single financing statement are subject to a possible weakness in bankruptcy. If on the date of the filing of the petition in bankruptcy one of the vehicles covered by such a document is within a jurisdiction where that foreign-noted interest is not valid against local lienors, ${ }^{91}$ the trustee in bankruptcy may be able to invoke section 70 (c) to avoid the interest in that vehicle. ${ }^{92}$ Arguably, if one creditor does in fact exist in the foreign jurisdiction, the interest might be voided as to all other vehicles covered by the document, under section 70 (e) as interpreted by Moore $v$. $B a y .^{93}$ In that case, a mortgage was invalidated as to all creditors even though the creditors who were actually superior to the mortgage could not claim the entire amount. The hypothetical presented here appears distinguishable, however, since here the actual superior creditors could in no circumstances claim prior rights over vehicles outside the foreign state. ${ }^{94}$ If this distinction is material, the secured party would lose only his interest in vehicles located in states not recognizing the foreign security interest.

\section{Purchase Money Interests}

Parties who lend on the security of after-acquired vehicles are subordinated by the Code to holders of purchase money security interests. ${ }^{95}$ A purchase money loan is defined as one given by a seller to secure all or part of the purchase price or "by a person who by making advances or incurring an

91. "Most courts refuse to uphold security interests perfected only in other states unless the lienor has not consented to the removal." Comment, 67 Y ALE L.J. 1024, 1046-49 $\&$ n.129 (1958) (collecting cases).

92. E.g., Chapman v. England, 231 F.2d 606 (9th Cir. 1956).

93. 284 U.S. 4 (1931).

94. See Wolf v. Aero Factors Corp., 126 F. Supp. 872 (S.D.N.Y. 1954), aff'd, 221 F.2d 291 (2d Cir. 1955) (mortgage of chattels in two counties upheld as to chattels located in county where mortgage was properly filed), cited in 4 Collrer $\{70.95$ n. $53 \mathrm{c}$. But sec Comment, 67 Y ALE L.J. 1024, 1056 (1958).

95. UCC $\$ 9-312(4)$. 
obligation gives value to enable the debtor to acquire right in or the use of collateral if such value is in fact so used." ${ }^{\prime 06}$ The critical section is 9-312(4), under which a purchase money interest in collateral other than inventory "has priority over a conflicting security interest," so long as the purchase money interest is perfected when the debtor receives possession of the collateral, or within ten days thereafter. ${ }^{97}$ In nontitle act states the only complication relating to purchase money loans relates to section 60 of the Bankruptcy Act.98 Section 9-301 provides that the purchase money interest will relate back to the time the interest was created if it is filed within ten days, thereby taking precedence over intervening lien creditors. Under section 60 (a) (7) of the Bankruptcy Act, if the lender does not perfect until the eleventh day after the debtor has received possession of the vehicle, the lender's interest will be a voidable preference, assuming that all of the other elements of a voidable preference are present. ${ }^{99}$ Moreover, if perfection of the purchase money interest is delayed beyond ten days, and the debtor's bankruptcy precedes that perfection, the trustee will be able to invoke section 70(c) of the Bankruptcy Act to set aside the purchase money interest. ${ }^{100}$ These threats aside, in nontitle act states a lender's purchase money interest, timely filed, will take priority over after-acquired property interests in the same vehicles.

No state title acts have been found which grant priority to purchase money interests over after-acquired property interests. Title act provisions stating that priority is determined by the order of notation or by the order of filing an application for notation ${ }^{101}$ seem to conflict with the Code rule. In actual practice, however, the title act priority rules would usually give priority to the purchase money lender. Since the purchase money lender will normally lend near the time of actual purchase, he can usually provide for immediate possession of the certificate covering the acquired vehicle, before any other secured party can obtain it. Notation of his interest on the certificate would thus occur prior to any other notation. The purchase money lender's position would be jeopardized in only a few situations. If another secured party obtains the certificate first, that party may prevail over the purchase money lender. Even this possibility may be avoided, however, if the title act provides a rela-

96. UCC $\$ 9-107$.

97. If the collateral is inventory vehicles, the purchase money interest will take priority over conflicting security interests only if it is perfected at the time the debtor receives the vehicles. The purchase money lender must also notify the holder of a conflicting interest before the debtor has received the collateral that the lender intends to acquire a purchase money interest in described inventory. UCC \$\$ 9-312(3) (a), -(b), -(c).

98. 52 Stat. 869 (1938), 11 U.S.C. $\$ \$ 96(a),-(b)$ (1958).

99. See 3 Collier $\$ 60.39$, at p. 919 ; Kennedy, supra note 75 , at 527-29.

100. 52 Stat. 879 (1938), 11 U.S.C. \& 110 (c) (1958). The most recent case interpreting $\$ 70$ (c), Lewis v. Manufacturers' Nat'l Bank, 364 U.S. 603 (1961), narrowed the trustee's power under this section by reversing the broad hypothetical lien creditor test articulated in Constance v. Harvey, 215 F.2d 571 (2d Cir, 1954).

101. See notes 66,67 supra. 
tion-back period ${ }^{102}$ and the purchase money lender applies for notation within that period, thus dating his security interest for purposes of priority from the time the purchase money agreement was created. ${ }^{103}$ Another possible way of subordinating the purchase money lender might arise if states adopted the fleet certificate proposal suggested above. Under that proposal, placing a description of the acquired vehicle on an existing fleet certificate already subject to an after-acquired property agreement has the effect of subordinating any purchase money interests which accompany the application for certification. That proposal should not be adopted, therefore, unless an explicit provision is included requiring a description on the certificate of the kind of interest noted and declaring that purchase money interests take priority.

It is desirable that purchase money security interests take priority over other types of security interests. The purchase money lender may be reluctant to advance funds if he must run the risk of being subordinated. Without such funds, there would often be no property to which the after-acquired property interest could attach. ${ }^{104}$ Purchase money interests perfected by notation might be accorded priority in several ways. One theory might engraft section 9-312 (4) on to the title act priority scale. Thus a title act clause which specifies that priority between security interests in a vehicle is strictly a function of the order of notation might be judicially read to include the section 9-312(4) treatment for purchase money interest. Such an analysis might be based on the axiom that a special act's silence on a particular issue should be supplemented by a later general act's solution to the problem. ${ }^{105}$ Of course, problems of judicial interpretation can be avoided by an amendment to Code state title acts, specifying that the section 9-312(4) rule of priority applies to noted interests. Recent proposed amendments to the Connecticut title act take this approach. ${ }^{106} \mathrm{By}$ whatever route this result is reached, it will necessitate a modification of any title act clause providing that the certificate should be delivered to the interest first noted on the certificate. ${ }^{107}$ Such clauses seem to be founded on the assumption that the interest first noted will actually have priority, an incorrect assumption in the case of purchase money interests.

102. A relation-back provision usually provides that if a security interest is perfected within a set period after its creation, it is treated as if perfected simultaneously with its creation. Ariz. Rev. Stat. Ann. § 28-325(e) (1956) ; VA. Code Ann. § 46.1-72 (1950); Utah Code Ann. § 41-1-86 (1953).

103. Ibid.

The Code provides that priority between conflicting security interests in the same collateral shall be determined by the order of perfection regardless of which security interest attaches first, "unless both are perfected by filing." UCC $\$$ 9-312(5) (b). In title act states adopting the code, those security interests perfected by notation on the certificate would not be interests "perfected by filing." See UCC \& 9-302(3) (b).

104. Cf. UCC \& 9-312 comment 3 .

105. 1 Suthertand $\$ 2021$ n.3 (citing cases).

106. Copy of proposed amendments on file in Yale Law Library.

107. See; e.g., Fla. Stat. Ann. \$ 319.24(3) (1958); Ohio Rev. Code Ann. § 4505.08 (Page, Supp. 1959). 
Accordingly, such title acts should be amended to provide for delivery of the certificate to the holder of the interest which is prior in right-an interest which may not necessarily be prior in time of notation.

\section{Mechanic's Liens}

Section 9-310 of the Code reserves a high priority lien to a mechanic for the value of services performed in repairing a motor vehicle. A lien for services or materials furnished in the ordinary course of business and "given by statute or rule of law" takes priority over perfected security interests-except where the statute creating the lien expressly provides otherwise-if the goods are in the possession of the person in whose favor such a lien arises. ${ }^{108}$ Some title acts explicitly agree with the Code's general policy of priority for mechanic's lienholders, ${ }^{109}$ although some limit the priority to a stated amount. ${ }^{110}$ Some title acts are ambiguous. They simply state that the notation of a security interest will "constitute constructive notice ... to . . . encumbrancers except such liens as may be authorized by a law dependent upon possession."'111 The negative pregnant of this provision is that actual notice of a perfected security interest defeats a mechanic's lien; so construed, these acts would not extend to a repairman the same protection that is afforded him under the Code. This reading, however, seems to stem from ambiguous drafting of a provision primarily designed to give mechanic's lien priority over the security interest noted on the title. Properly construed, it would conform generally to the result obtaining under the Code.

One of these ambiguous statutes, however, has been construed, by a different rationale, to subordinate mechanic's liens altogether. ${ }^{112}$ This statute is thus in direct conflict with section 9-310 of the Code which permits the subordination of a mechanic's lien only when the "statute creating such a lien" provides that it shall be subordinated. ${ }^{113}$ This statement of the Code rule appears to mean that if the statute which created the lien did not subordinate it, the title act cannot make it inferior to other interests. ${ }^{114}$ It can be argued that a title act's subordination clause pertaining specifically to motor vehicle mechanic's liens prevails over the more general mechanic's lien section of the Code. ${ }^{116}$ On the other hand, the comment to section 9-310 asserts that "if the

108. UCC $\S 9-301$.

109. A number of title acts expressly give the repairman priority over noted security interests. See, e.g., D.C. Code Ann. $\$ 38-205$ (Supp. 1960) ; CAL. Ver. Code $\S 6301$ (1960); Cal. Civil Cone $\$ 3068$ (Supp. 1960).

110. See, e.g., Nev. Rev. Stat. $\$ \S 482.440,108.290$ (1957) ; VA. Code AnN. § 46.1-73 (1950) (priority to the extent of $\$ 50$ ).

111. N.M. Stat. Ann. § 64-5-2(a) (1953) ; Tenn. Code Ann. § 59-327 (1955).

112. City Fin. Co. v. Perry, 195 Tenn. 81, 257 S.W.2d 1 (1953).

113. Emphasis added.

114. Where the subordination of the mechanic's lien is effected by the mechanic's lien statute itself, see Wis. Stat. ANN. $\$ 289.41$ (1) (1958) (subordinating amounts over a fixed sum), the Code will have no effect. See also Neb. Rev. Stat. AnN. \$\$ 52-201, -203.

115. See 1 SutherLand $§ 2021$. 
statute creating the lien is silent, even though it has been construed by decision to make the lien subordinate to the security interest, this section [9-310] provides a rule of interpretation that the lien should take priority over the security interest."116

Analysis of the commercial significance of mechanic's liens seems to dictate that section 9-310 be construed as repealing the provisions of any title act subordinating mechanic's liens. Those title act provisions seem to assume that the mechanic can easily determine whether a vehicle is subject to a security interest by inspecting the certificate of title, and can protect himself from becoming a junior lienholder. Even in a state in which the certificate is delivered to the holder of the senior security interest, a mechanic would be put on notice that the vehicle might be subject to a security interest by the debtor's inability to produce the certificate. ${ }^{117}$ This reasoning implies that a mechanic, knowing the vehicle to be subject to a security interest, can assure payment of his claim either by refusing to work on the vehicle without payment in advance, or by seeking a subordination agreement from the prior secured party. This inconvenient procedure seems undesirable; to the extent that repair is actually discouraged by this procedure, the priority system seems particularly onerous in the motor vehicle repair field, since the vehicles are so frequently needed for daily use. ${ }^{118} \mathrm{~A}$ better approach would be to assume that the secured party has impliedly consented to all reasonable repairs. ${ }^{119}$ The mechanic has presumably increased the value of the vehicle by an amount at least roughly correspondent to the reasonable cost of his repairs. The mechanic should, therefore, take priority to the extent of his contribution to the enhanced value of the vehicle, as measured by his lien.

\section{Interstate Recognition of Motor Vehicle Security Interests}

The effect in a Code state of security interests created elsewhere varies according to three factors: First, whether or not a title act is in operation in the Code state; second, whether or not the security interest was created and perfected in a title act state; and, third, the nature of the motor vehicle securing the transaction. Section 9-103 of the Code divides vehicles into two categories: "equipment or inventory"120 are those "used or bought for use pri-

116. UCC \& 9-310 comment 2.

117. Note, 33 Cons. B.J. 474, $478-79$ (1959). But see cases subordinating mechanic to interests perfected in a foreign nontitle act state. Nelson-Collins-Nash, Inc. v. Associates Discount Corp., 193 Tenn. 696, 249 S.W.2d 902 (1952); American Loan Co. v. See, 298 Ky. 180, 182 S.W.2d 644 (1944). Consider the problem in the context of 72 Stat. 812 (1958), 49 U.S.C. $\$ 313$ (1958). See text at notes 141-56 infra.

118. But see Ehrlich v. Chapple, 311 I11. 467, 143 N.E. 61 (1924). See also 7A Blashfield, Cyclopedia of Automobile Law and Practice $\$ 5162$ (perm. ed. 1950).

119. A number of cases have found consent implied on various theories, e.g., possession by the debtor. See, e.g., Etchen v. Dennis \& Son Garage, 104 Kan. 241, 178 Pac. 408 (1919). Guaranty Sec. Corp. v. Brophy, 243 Mass..597, 137 N.E. 751 (1923).

120. UCC $\$ 9-103(2)$. 
marily in business" (equipment), ${ }^{121}$ or held for lease by the debtor to others (inventory) $;^{122}$ the second category encompasses all other vehicles. ${ }^{123}$ The first category will be referred to herein as "equipment."

\section{Equipment Vehicles}

Section 9-103(4) of the Code provides that where any vehicle is covered by a certificate issued in a mandatory-notation title act state, perfection of security interests in that vehicle is "governed by the law of the jurisdiction which issued the certificate." If the Code state has a title act of its own, incorporated into the Code, this provision must be interpreted in light of that title act. Some state title acts forbid the sale or encumbrance of any vehicle not covered by a certificate of title issued locally, ${ }^{124}$ and others require that a local certificate be obtained after arrival. ${ }^{125}$ These provisions would seem to continue in force when the Code is adopted. When a new certificate is issued pursuant to local law, the law governing the security interest would then seem to be local law. Implicit in subsection 4 , therefore, must be the notion that perfection is governed by the law of the state which issued the first certificate, until such time as the local title act requires the issuance of a new certificate.

When an "equipment" vehicle is not covered by a certificate of title under a law which requires notation of security interests on the certificate, section 9-103(2) provides that a party wishing to perfect a security interest in such a vehicle must do so under the law of the "chief place of business" of the debtor. "Chief place of business" is not defined in the text of the Code. In a comment to section 9-103, however, the drafters note that the phrase means "the place from which in fact the debtor manages the main part of his business operation," rather than the place of incorporation; it is the "place where persons dealing with the debtor would normally look for credit information."126

121. UCC \& 9-109(2).

122. UCC $\S 9-109(4)$.

123. UCC $\$ 9-103(3)$.

124. See, e.g., Fla. Stat. Ann. $\$ \$ 319.21,-.22$ (1958); see also Conn. Gen. Stat. ANN. $\$ \$ 14-169,-16$ (1960) (pertaining to sale).

125. E.g., PA. Star. ANN. tit. 75, \& 201 (1960).

126. UCC \& 9-103 comment 3 .

A similar policy function appears to underlie the notion of a "principal place of business" in two federal statutes which have been the subject of judicial interpretation- $\$ 2(1)$ of the Federal Bankruptcy Act, 66 Stat. 420 (1938), 11 U.S.C. $\$ 11$ (a) (1958), and $\$ 1332$ (c) of the Judiciary Act, 28 U.S.C. $\$ 1332$ (c) (1958). Congress has directed that $\$ 2$ (1) of the Bankruptcy Act furnish the criteria for determining "principal place of business" under $\S 1332$ (c) of the Judiciary Act. S. REP. No. 1830, 85th Cong., 2d. Sess. (1958) in 2 U.S. Code Cong. \& AD. News 3099, 3100 (1958). Under $\$ 1332$ (c) of the Judiciary Act "principal place of business" has been defined as "the nerve center from which (the corporation) radiates out to its constituent parts and from which its officers direct, control, and coordinate all activities, without regard to locale, in the furtherance of the corporate objective." Scott Typewriter Corp., Inc. v. Underwood Typewriter Corp., 170 F. Supp. 862 (S.D.N.Y. 1959). One bankruptcy court has suggested a possibly contrary view. See In re Hudson River Nav. Corp., 59 F.2d 971 (2d Cir. 1932) (dictum suggesting that prin- 
Pending judicial approval of these definitions, however, the drafters advise prospective secured parties to file in several places. ${ }^{127}$

Once a prospective secured party has determined that an equipment vehicle is not covered by a mandatory notation certificate of title, and has located the debtor-owner's chief place of business, section 9-103(2) directs the secured party to perfect his interest in that jurisdiction. If the debtor's chief place of business is in a non-Code state, the secured party may encounter a rule in that state preventing the valid perfection of security interests in chattels not situated within that state. ${ }^{128}$ In such cases the secured party must file wherever the conflict of laws rules of the chief-place-of-business state provide that the interest should be perfected. ${ }^{129}$ Under accepted conflicts rules, the state of the chief place of business will recognize a perfection made at the situs of the chattel. ${ }^{130}$ Since the Code applies only when the chattel is situated within the Code jurisdiction, ${ }^{131}$ this rule would mean in practice that the secured party must file in the Code state if the chief-place-of-business state refuses recordation-as the Code itself provides. ${ }^{132}$

There is, however, a substantial exception to the rule granting recognition to situs filing: if the secured party has consented to the removal of the vehicle from its situs at the time of perfection, there are a number of states which will not recognize an interest perfected at that situs. ${ }^{134}$ If the lender knew that the vehicles were to be used in more than one jurisdiction, consent will be presumed. ${ }^{135}$ Since section 9-103(2) applies to vehicles "of a type which are normally used in more than one jurisdiction," that rule would probably apply to many security interests covered by this section. Not all interests will be subject to the consent rule, however, since a vehicle of the "type" described in section 9-103(2) may not, in fact, be one which the parties contemplate using in another state. Under the "consent" rule, a security interest attaching to the vehicle in a non-Code jurisdiction would take priority over the interest perfected at an earlier situs of the vehicle. ${ }^{136}$ More significantly, if the jurisdiction to which the vehicle has been removed allows some general creditors to obtain a judicial lien on property covered by a belatedly filed mortgage, the

cipal place of business of a transportation corporation is jurisdiction in which its vehicles travel the most revenue-miles).

127. UCC \& 9-103 comment 3.

128. See, e.g., Vevaris v. Egan, 226 I11. App. 500 (1922) ; Stumberg, Chattel Security Transactions and the Conflict of Laws, 27 IowA L. REv. 528, 546 (1942).

129. UCC \$ 9-103(2).

130. See authorities cited note 27 supra.

131. UCC \& 9-103 comment 1, referring to UCC \$ 9-102.

132. UCC \$ 9-103(2).

133. See authorities cited note 27 supra.

134. See, e.g., Memphis Bank \& Trust Co. v. West, 260 S.W.2d 866 (Mo. Ct. App. 1953); Universal Fin. Co. v. Clary, 227 N.C. 247, 41 S.E.2d 760 (1947) ; Mrch. Stat. AnN. \$ 26-929 (Supp. 1959) ; Restatenent, Conflict of Laws $\$ \$ 265-78$ (1934).

135. See Robbins v. Bastian, 138 F.2d 622 (8th Cir. 1943); United Constr. v. Afilan, 124 F.2d 670 (6th Cir. 1942).

136. See cases cited note 134 supra. 
trustee in bankruptcy may be able to avoid the entire security interest in the vehicle under section $70(\mathrm{e})$, provided that one such general creditor actually exists. ${ }^{137}$

On the other hand, if the debtor's chief place of business is in a Code state, the secured party will have no difficulty in filing his interest there. ${ }^{138}$ That interest may not be recognized, however, in a non-Code state whose conflicts rules require that an interest in $a$ chattel be perfected at its situs. Here the general rule upholding security interests perfected at the situs of the chattel at the time the interest attached works against the secured party, since courts following the rule would probably not recognize chief-place-of-business filing in lieu of situs filing. Thus when a chattel mortgage is executed and perfected in a Code state, on property located in another state, the law of the situs will normally govern its effectiveness. ${ }^{139}$ If the interest is not perfected in the situs state, lien creditors or a trustee in bankruptcy can prevail over the secured party.

Application of the "situs jurisdiction" rule in these cases seems particularly harsh where mobile chattels are involved. It would seem preferable to accept the Code view that the secured party has acted properly in perfecting his interest in the place where any subsequent creditor is most likely: to look for information. ${ }^{140}$

\section{Federal Law}

Section 313 of Title 49 of the United States Code makes special provision for certain vehicies that are within the "equipment or inventory" category of section 9-103(2) of the Uniform Commercial Code. This federal enactment, of course, governs in any case of conflict between it and a state statute. The federal statute is directed towards large motor trucks and buses owned or leased by interstate carriers certificated by the Interstate Commerce Commission. ${ }^{141}$ It is designed to relieve holders of security interests in such vehicles of the need to perfect their interests in every jurisdiction through which the vehicles might pass. ${ }^{142}$ Congress rejected one obvious method for achieving this end-the establishment of a national filing office, the records of which

137. See text at notes 93-94 supra.

138. Filing is authorized by UCC $\$ 9-103(2)$.

139. E.g., Steckel v. Swift \& Co., 56 S.W.2d 806 (Mo. App. 1933); see authorities cited note 27 supra; see generally Note, 66 Y ALE L.J. 567 (1957).

140. See UCC \$ 9-103 comment 3. See also Comment, 9 Ax. J. Comp. L. 458 (1960).

141. 72 Stat. 812 (1958), 49 U.S.C. § 313(a)(1) (1958). A motor vehicle governed by the act must be a) a truck having a rated capacity (gross vehicle weight) of ten thousand pounds or more; or $\mathbf{b}$ ) a highway tractor having a rated capacity (gross combination weight) of ten thousand pounds or more; or c) a property-carrying trailer or semi-trailer having one or more load-carrying axles of ten thousand pounds or more; or d) any motor bus having a seating capacity of ten persons or more. 78 Stat. 812 (1958), 49 U.S.C. $\$ 313(\mathrm{a})(6)$ (1958).

142. H.R. Rep. No. 2354, 85th Cong., 2d Sess., in 2 U.S. Code Cong. \& AdMr. News 3773-74 (1958); see Comment, 67 Y ALE L.J. 1024, 1043-58 (1958). 
would constitute constructive notice of perfected security interests in these large vehicles. ${ }^{143}$ It provided instead that any security interest in a vehicle owned or leased by a certificated carrier which secures an underlying obligation of that carrier may be perfected by notation on any certificate of title covering the vehicle. ${ }^{144}$ In addition, if no certificate of title covers the vehicle, the security interest may be perfected under the recording system of the home state-defined as equivalent to the Code's "chief place of business"145-of the debtor carrier. ${ }^{146}$ Finally, if the vehicle is not covered by a certificate of title, and recording of the interest in the home state is not possible, the "law" of the home state is to govern perfection. ${ }^{147}$ The act validates a security interest perfected in accordance with the act "against all general creditors of, and subsequent lien creditors of, and all subsequent purchasers from, the debtor carrier."148 This statute, therefore, does not constitute the exclusive method of perfecting a security interest in a vehicle; it merely gives priority over subsequent secured parties to those who comply with its mechanism. Consequently, a prospective secured party must still carefully check the many perfection routes by which interests in the vehicle may have been perfected prior to the perfection of his own interest. A mere check of the records in the home state of the debtor carrier will not guarantee a secured party that a vehicle is free of prior security interests perfected in another state.

When a motor vehicle is covered by any certificate of title, the federal statute grants priority to interests noted on the certificate. ${ }^{149}$ However, under the applicable title act one party may be unable to perfect certain types of security interests by notation. For example, several title acts do not provide for the notation of leases. ${ }^{150}$ "Leases" are regarded as security interests by the federal statute, presumably referring to the "security lease" concept of the Uniform Commercial Code which recognizes that some leases may be little more than a financing arrangement whereby the secured party holds nominal title, and the "rent" payments actually constitute payments on the loan. ${ }^{101}$ If a lessor is refused the right to note his interest on a certificate of title covering a leased vehicle, he cannot realize the benefit of the federal statute if he

143. Id. at 3774-75. Security interests in railroad rolling stock are so perfected, 49 U.S.C. $\$ 20 \mathrm{c}$ (1958), as are interests in ships, 41 Stat. 1000 (1920), as amended, 46 U.S.C. $\S \S 911-84$ (1958), and aircraft, Civil Aeronautics Act, $\S 503$, 52 Stat. 1006 (1938), as amended, 49 U.S.C. § 523 (1958).

144. 72 Stat. 812 (1958), 49 U.S.C. $\$ 313$ (b) (1958).

145. H.R. No. 2354, supra note 120, at 3773 .

146. 72 Stat. 812 (1958), 49 U.S.C. \& 313(c) (1958).

147. 72 Stat. 812 (1958), 49 U.S.C. $\S 313$ (d) (1958).

148. 72 Stat. 812 (1958), 49 U.S.C. $\S 313(\mathrm{~b}),-(\mathrm{c}),-$ (d) (1958).

150. See, e.g., LA. Rev. Stat. Ann. § $32: 710$ (A) (1950) ; Nev. Rev. Stat. $\S 482.425$ (1960). Both refer only to chattel mortgages.

151. See UCC $\$ 1-201(37)$. The advisors to the draftsmen of the federal statute included several of those who participated in preparing the Uniform Commercial Code. See H.R. REP. No. 2354, supra note 142 , at 3775 . 
then uses another form of recordation in the carrier's home state. The act states that only a security interest in a vehicle "for which a certificate of title has not been issued" can be perfected otherwise than by notation. ${ }^{\mathbf{1 5 2}}$ This reading of the statute might be regarded as the product of a poorly drafted attempt to provide alternative means of filing all interests. On the other hand, failure to protect leases which cannot be noted might be justified by the view that, if a vehicle has a certificate, it should not be subject to nationally perfected interests which do not appear on the certificate. The effect of this reading is to deprive the secured party of the federal act's guarantee that his interest will be recognized against all subsequent secured parties. In this situation, the lessee's only recourse is to perfect his interest wherever he can record-for example, the home state of the debtor carrier, his own residence, or states in which the vehicle may at some time be located-and to rely upon the courts of other states to recognize that interest against subsequent interests conveyed by the lessor and perfected under the federal act. ${ }^{153}$

The federal statute may prove similarly ineffectual where a motor vehicle is not covered by a certificate of title, and where the home state of the debtor carrier insists that security interests in chattels not located within the state be perfected at their situs. In these cases subsection (d) of the federal act directs the secured party to the conflict of laws rules of the home state in order to determine where to perfect his interest. ${ }^{154}$ These rules in non-Code states usually indicate that the situs of the vehicle at the time the interest attaches is the proper place to record. ${ }^{155}$ Perfection there would have nationwide effect against subsequent secured parties dealing with the debtor carrier. Assume, however, that a subsequent secured party attempted to acquire an interest in a vehicle after it had been moved from the jurisdiction where a prior interest was perfected. If he looks to the conflicts rules of the home state at that time, they would direct him to the recording system of the new situs of the vehicle. These records, of course, would not disclose the security interest previously perfected at the former situs. The subsequent secured party would then have to search the recording systems of all the jurisdictions in which the vehicle might at one time have been located-the same situation which would have confronted him had there been no federal act. This defect might be remedied by deleting subsection (d), and by providing that recordation in the home state would constitute valid perfection under the federal statute, whatever its status under state law. Such a provision would be unworkable only in the unlikely event that the state agency would refuse to record. ${ }^{156}$ Of course, as more states enact the Uniform Commercial Code, this

152. 72 Stat. 812 (1958), 49 U.S.C. \& 313(c) (1958).

153. See text at note 148 supra.

154. See 72 Stat. 812 (1958), 49 U.S.C. § 313(d) (1958).

155. See text at note 130 supra.

156. Cf. Buck v. Kuykendall, 267 U.S. 307 (1925) (refusal of state to issue certificate necessary for interstate motor carrier to use state highways was undue restriction forbidden by the commerce clause). 
problem will be alleviated by section 9-103(2) which expressly permits recordation in the home state of a debtor carrier.

\section{Nonequipment Vehicles}

Security interests created in a foreign state in motor vehicles which are not classed as "equipment" or "inventory" under section 9-103(2) of the Code are governed by sections 9-103(3) and 9-103(4). ${ }^{157}$ These two sections address themselves to three possible situations: 1) If the incoming vehicle is not covered by a mandatory notation certificate of title, any security interest perfected in a foreign state continues perfected in the Code state for four months; if the secured party perfects within the Code state within that four month period, the interest remains perfected from the date of original perfection in the foreign state. ${ }^{158}$ If the secured party fails to re-perfect his interest within four months, a later re-perfection does not date back to the date of the original perfection. ${ }^{159}$ 2) If the security interest was not perfected in the foreign state, it may be perfected in the Code state after the vehicle has been brought there. This perfection does not relate back to the time when the interest was created in the foreign state; rather, it dates from the time of perfection in the Code state. ${ }^{160} 3$ ). If the incoming vehicle is covered by a certificate of title which requires notation of all security interests, any interest so noted will be accorded priority over subsequently perfected interests. ${ }^{161}$ Parties wishing to perfect interests in vehicles which are covered by out-of-state certificates of title must exercise the same caution as the holder of a security interest in an equipment vehicle. ${ }^{162}$ First, the secured party must determine if his interest has been noted on a mandatory-notation certificate of title; if not, he must re-perfect that interest within four months of the vehicle's entry into the Code state. Second, interests perfected through mandatory-notation certificates are governed by the law of the issuing jurisdiction only until such time as the Code state's title act may require the issuance of a new certificate.

Section 9-103(3) guarantees that security interests perfected in nonmandatory notation states will remain perfected for four months in a Code state. During this four month period the holder of such an interest is accorded the same protection as if he had perfected in the Code state itself. ${ }^{103}$ After four months have elapsed the interest stands on the same footing in the Code state as any other unperfected interest. ${ }^{164}$ Subsequent secured parties who perfect

157. See UCC §§ 9-109(2), -(4).

158. UCC \$9-103(3). For a similar provision, see Unifarm Motor Vehicle Certificate of Title and Asti-Theft Act, 9B UNIFORM LAws ANN. \$ 20 (1957).

159. Ibid.

160. Ibid.

161. UCC § 9-103(4).

162. See text at notes 124-25 supra.

163. UCC \$ 9-103 comment 7.

164. UCC \$ 9-103 comment 7. See also UCC \$ 9-403 comment 3 . 
their interests in the Code state will prevail over the secured party who failed to re-perfect. ${ }^{165}$ Lien creditors without knowledge of the existence of a prior interest will also take priority over such an interest if they obtain liens before it is perfected. ${ }^{166}$ And buyers not in the ordinary course of business who acquire the vehicle without knowledge of a pre-existing interest in it will take free of that interest to the extent that they give value and take delivery. ${ }^{167}$ Of course, even if the out-of-state security interest is never re-perfected in the Code state, it will prevail over lien creditors and buyers not in the ordinary course of business who have notice of its existence. ${ }^{108}$

Article Nine's provision that incoming security interests remain perfected in the Code state for a four month period may conflict with either of two types of title acts that may be in force in a jurisdiction enacting the Code. Some title acts make no mention of foreign security interests. ${ }^{169} \mathrm{~A}$ court construing such a statute may determine that the local title act was meant to be preemptive in matters concerning motor vehicle security interests. In such a case some courts might apply the pre-Code doctrines which had the effect of subordinating incoming security interests to local purchasers and lien creditors. ${ }^{170}$ It seems preferable, however, to construe the Code's positive statement of policy on this point as superseding the common law drawn from a statute silent on the subject. ${ }^{\mathbf{1 7 1}}$ Under this interpretation, the incoming security interests would remain perfected for four months without notation on the Code state's title certificate.

The second type of title act which may conflict with section 9-103(3) is the title act which purports to deal with foreign security interests. For example, section 20 of the Uniform Motor Vehicle Certificate of Title and AntiTheft Act ${ }^{172}$ recognizes a security interest noted on any type of title certificate issued by the jurisdiction where the vehicle was located when the interest attached; the Code recognizes such an interest only if notation is mandatory under the foreign law, but recognition of such interests is not affected by whether the vehicle was located in the jurisdiction issuing the certificate. . $^{173}$ If the interest is perfected in a nontitle act jurisdiction in which the vehicle was located at the time the interest was created, the Uniform Act provides

165. UCC \& 9-103 comment 7.

16.6. UCC $\S 9-301(\mathrm{~b})$.

167. UCC $\S \S 9-301(b),-(c)$.

168. See text at note 58 supra.

169. E.g., VA. Code ANN. § 46.1-1 (Supp. 1950) ; Pa. Stat. Ann. tit. 75, § 101 (1960); see Note, 45 VA. L. REv. 754, 758-60 (1959).

170. See text at notes $28-29$ supra.

171. Where a special or local statute purports to treat a particular subject matter but fails to provide for a given circumstance the general law on the subject will be considered as supplementing the special law by supplying the law to govern that situation.

1 Sutherland $\S 2021$ n.3 (citing cases).

172. 9B UNIFoRM LAwS ANN. § 20.

173. UCC $\S 9-103(4)$. 
that it continues perfected for four months after a certificate of title is issued in the Uniform Act state ${ }^{\mathbf{1 7 4}}$ under the Code, such interests continue perfected for four months after entry into the Code state. ${ }^{175}$ The difference between the provisions is illustrated by the situation in which the owner is not required to obtain a new certificate in the second state for, say, one year. While the Code protects security interests in such vehicles for only four months after entry, the Uniform Act presumably regards the interest as perfected for one year and four months more. The Code-Uniform Act state may, of course, avoid most of the conflict if its title act provides that a certificate of title must be issued for the vehicle immediately upon its arrival, or soon thereafter. But the remaining possibility of conflict between the protection granted by the Code and by the Uniform Act dictates that Uniform Act states adopting the Code should repeal any provisions in their title acts dealing with foreign-created security interests, providing instead that section 9-103(3) and (4) will govern foreign-perfected interests. A similar amendment has been proposed in Connecticut. ${ }^{176}$ This amendment might well be adopted in all title act states which enact the Code. Courts dealing with title acts which are silent on the matter of foreign security interests will be relieved of the temptation to bypass the Code and apply the older "common law."

174. 9B UNIForm LAws ANn. $§ 20$.

175. UCC § $9-103(3)$.

176. Copy of proposed amendments on file in Yale Law Library. The proposal also provides for the inclusion of subsection (2)'s priority rules, relating to equipment vehicles. 